\title{
The Root-Associated Microbial Community of the World's Highest Growing Vascular Plants
}

\author{
Roey Angel ${ }^{1,2} \cdot$ Ralf Conrad $^{1} \cdot$ Miroslav Dvorsky $^{3} \cdot$ Martin Kopecky $^{3}$. \\ Milan Kotilínek $^{4}$ • Inga Hiiesalu ${ }^{3}$ - Fritz Schweingruber ${ }^{5}$ - Jiř́i Doležal ${ }^{3,4}$
}

Received: 4 January 2016 / Accepted: 3 May 2016 / Published online: 31 May 2016

(C) The Author(s) 2016. This article is published with open access at Springerlink.com

\begin{abstract}
Upward migration of plants to barren subnival areas is occurring worldwide due to raising ambient temperatures and glacial recession. In summer 2012, the presence of six vascular plants, growing in a single patch, was recorded at an unprecedented elevation of 6150 m.a.s.l. close to the summit of Mount Shukule II in the Western Himalayas (Ladakh, India). Whilst showing multiple signs of stress, all plants have managed to establish stable growth and persist for several years. To learn about the role of microbes in the process of plant upward migration, we analysed the root-associated microbial community of the plants (three individuals from each) using microscopy and tagged amplicon sequencing. No mycorrhizae were found on the roots, implying they are of little importance to the establishment and early growth of the plants. However, all roots were associated with a complex
\end{abstract}

Electronic supplementary material The online version of this article (doi:10.1007/s00248-016-0779-8) contains supplementary material, which is available to authorized users.

Roey Angel

angel@microbial-ecology.net

1 Max Planck Institute for Terrestrial Microbiology, Karl-von-Frisch-Str. 10, Marburg, Germany

2 Present address: Division of Microbial Ecology, Department of Microbiology and Ecosystem Science, University of Vienna, Althanstrasse 14, Vienna, Austria

3 Institute of Botany, The Czech Academy of Sciences, Zámek 1, 25243 Průhonice, Czech Republic

4 Department of Botany, Faculty of Science, University of South Bohemia, Na Zlate stoce 1, 37005 Ceske

Budejovice, Czech Republic

5 Swiss Federal Research Institute WSL, Zuercherstrasse 111, 8903 Birmensdorf, Switzerland bacterial community, with richness and diversity estimates similar or even higher than the surrounding bare soil. Both soil and root-associated communities were dominated by members of the orders Sphingomonadales and Sphingobacteriales, which are typical for hot desert soils, but were different from communities of temperate subnival soils and typical rhizosphere communities. Despite taxonomic similarity on the order level, the plants harboured a unique set of highly dominant operational taxonomic units which were not found in the bare soil. These bacteria have been likely transported with the dispersing seeds and became part of the root-associated community following germination. The results indicate that developing soils act not only as a source of inoculation to plant roots but also possibly as a sink for plant-associated bacteria.

Keywords Vascular plants · Upward migration · Subnival soil $\cdot$ Plant-associated bacteria

\section{Introduction}

One of the most apparent consequences of global warming is the upward migration of plants to higher elevations, from which they were previously excluded [1]. In some cases, plants have been able to migrate to entirely unvegetated areas in the subnival zone, which were previously too cold to permit growth or only recently exposed due to glacial recession (e.g. [2-4]). These subnival soils are usually very young and poor. Soil development from the eroded bedrock is largely a combination of physicochemical processes, such as cryoturbation and mineral leaching, and of microbial processes (including chemical weathering and nitrogen fixation) [5].

Since microorganisms are easily dispersed by wind and, on the whole, more stress-tolerant than plants, they colonise 
subnival zones before plants do. Several studies have documented the presence of bacteria [6-8], archaea $[7,9,10]$ and fungi [7] in subnival zones and glacial forefields within a few years from deglaciation and have monitored the subsequent succession of microbial communities. Whilst the particular bacterial community structure varied by site, some common early colonisers in the forefields of receding glaciers from different regions worldwide included members of the phyla alpha-, beta-, gamma- and deltaproteobacteria, Bacteroidetes, Cyanobacteria, Actinobacteria and Acidobacteria. Although these phyla are typical also of mature soils in temperate regions, their proportions in subnival zones differed significantly from mature soils and were composed of high proportions of Betaproteobacteria and Cyanobacteria, for example. In the absence of plants, biological soil crusts develop in subnival zones and photosynthesis and nitrogen fixation are mainly carried out by Cyanobacteria and other microorganisms living in the crust [10-13].

With the subsequent colonisation and establishment, vascular plants further promote the processes of soil development by enriching the soil with organic matter through rhizodeposition and foliage and by promoting weathering of the bedrock [14]. Much like microbes, specific plants are known to be particularly suitable as pioneers of subnival zone soils $[15,16]$. These often include compact and wind- and frost-tolerant species, which are able to grow on poor soils and during short growing seasons [17]. The portion of the soil directly surrounding the plant roots, known as the rhizosphere, and the root surface itself (rhizoplane) are a hot spot for microbial activity, which is stimulated by the added carbon provided by root exudates and sloughing of cells [18]. This plantmediated stimulation of microbial activity in the rhizosphere speeds up soil formation. However, the rhizosphere and rhizoplane are not simply sites of stimulated activity; rather, plants also select for a specific root-associated microbial community, which differs from the surrounding bulk soil [19]. The root-associated bacterial community composition may differ with plant species [20], though it is commonly dominated by alphaproteobacteria (such as Rhizobia), betaproteobacteria (e.g. Burkholderia), gammaproteobacteria (such as Pseudomonas), Firmicutes (e.g. Bacillus) and Bacteroidetes [21].

The Northwestern Himalayas is an extensive and thinly populated high-altitude cold desert characterised by low temperatures and low precipitation owing to its location in the Himalayan rain shadow [22]. This region has been experiencing an accelerated rise in temperature with rapidly retreating glaciers during the 1990s [23, 24], whilst over the last decade there has been a general shift towards rainy (often snowy) summers, a prolonged growing season and unpredictable extreme precipitation events [25]. In an expedition performed in the summer of 2012 to study the plant diversity and the soil microbiology of the region, we have recorded a small and sparse patch of vegetation close to the summit of Mount Shukule II, India, at an unprecedented elevation of 6150 m.a.s.l. In this patch, we identified six vascular species: Draba alshehbazii, Draba altaica, Ladakiella klimesii, Poa attenuata, Saussurea gnaphalodes and Waldheimia tridactylites (Fig. 1).

In this study, we collected three individual plants from each species. Using barcoded Illumina MiSeq amplicon sequencing of the SSU rRNA gene, we characterised the rootassociated bacterial community of the plants and that of the adjacent bare soil. In addition, we analysed the chemical composition of the bare soil and plant tissues and determined the plant age. We hypothesised that since microorganisms precede plants in colonising subnival soils and are required by plants
Fig. 1 Six vascular plant species discovered at 6150 m.a.s.l.: Draba alshehbazii, Draba altaica, Ladakiella klimesii, Poa attenuata, Saussurea gnaphalodes and Waldheimia tridactylites

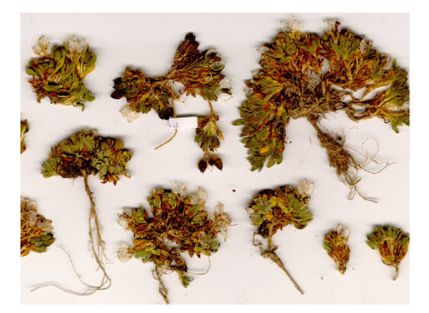

$$
\text { D. alshehbazii }
$$

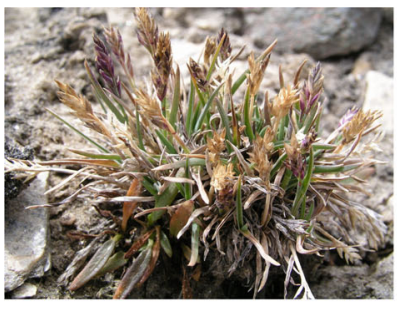

P. attenuata

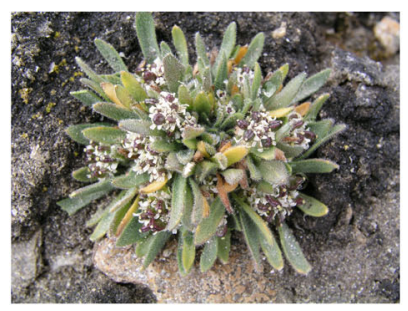

D. altaica

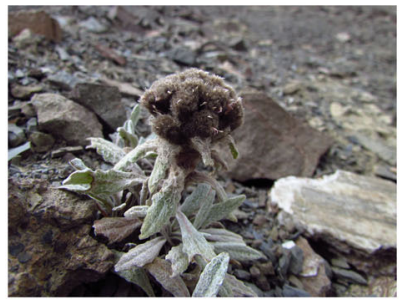

S. gnaphalodes

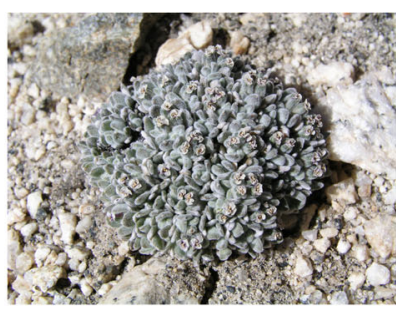

L. klimesii

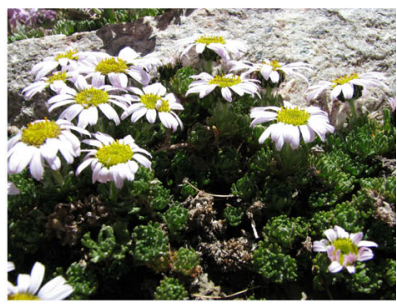

W. tridactylites 
for the supply of minerals and fixed nitrogen, the rootassociated bacteria of the plants will be a selected subset of the community found in the soil, particularly comprising organisms capable of nitrogen fixation.

\section{Materials and Methods}

\section{Study Site and Sampling Technique}

The presence of six vascular plant species was recorded at an unprecedented elevation of 6150 m.a.s.l. close to the summit of Mount Shukule II in the Northwestern Himalayas (southwest spur of the Tibetan Plateau in Eastern Ladakh, Jammu and Kashmir State, India), $15 \mathrm{~km}$ east of Tso Moriri Lake $\left(32^{\circ} 59^{\prime} \mathrm{N}, 78^{\circ} 30^{\prime} \mathrm{E}\right.$; Fig. S1). The plants were growing in a single and small patch on a southwest-facing small boulder field (approx. $1 \mathrm{ha}$ ) on an undeveloped calcareous soil. The region is arid (Leh: $115 \mathrm{~mm}$ year $^{-1}$, 3514 m.a.s.l., approx. $170 \mathrm{~km}$ northwest of the study region; Gar: $54 \mathrm{~mm}_{\text {year }}{ }^{-1}$, 4232 m.a.s.l., approx. $160 \mathrm{~km}$ southeast of the study region) because most of the summer monsoon precipitation is blocked by the main Himalaya Range, as well as the range of Hindu Kush stands as a barrier to the westerly disturbances, which bring winter precipitation to this region. A TMS data logger (see below) was installed on the spot in 2011, and on 15 August 2012 three individuals from each species were sampled with intact root systems as possible. The roots were separated from rhizospheric soil (by shaking and washing in glacial water), cut from the shoot and dried in clean paper bags. In addition, dry bare soil ( 0 - to $5-\mathrm{cm}$ depth) from the same site (approx. $1 \mathrm{~m}$ apart from the patch) was also sampled in six replicates for comparison and stored in clean paper bags until further analysis.

\section{Plant Species}

The following species were studied in this work (www. efloras.org/) [26]:

L. klimesii (Al-Shehbaz) D. A. German \& Al-Shehbaz (Brassicaceae) is a perennial herb forming compact cushions $1-3 \mathrm{~cm}$ tall and $2-10 \mathrm{~cm}$ in diameter. It has a single unbranched tap root with few lateral fine roots. The species is endemic to the western part of the Tibetan Plateau (E. Ladakh, W. Xizang) and grows in subnival zones near the snowline. In Ladakh, this species occurs from 5350 to 6150 m.a.s.l., with optimum around 5800 m.a.s.l.

D. altaica (C. A. Mey.) Bunge (Brassicaceae) is a perennial herb forming compact cushions $2-8 \mathrm{~cm}$ tall and $1-5 \mathrm{~cm}$ in diameter, with a main tap root and many fine lateral roots. Its distribution range encompasses the continental Central Asiatic mountains from southern Siberia and Kazakhstan to Mongolia. It grows in rock crevices, on stabilised slopes, on moraines and at streamsides. In Ladakh, the species occurs at 3420-6150 m.a.s.l., with optimum around 5500 m.a.s.l.

D. alshehbazii Klimeš \& D. German (Brassicaceae) is a perennial herb forming compact cushions 1-2 $\mathrm{cm}$ tall and 1$5 \mathrm{~cm}$ in diameter, with a main tap root and many fine lateral roots. So far, the species is known from several localities in eastern Ladakh, but its presence in China (W. Xizang) is also expected. It is restricted to subnival zones at altitudes from 5470 to 6000 m.a.s.l., with most localities situated above 5700 m.a.s.l.

W. tridactylites Kar. \& Kir. (Asteraceae) is a perennial herb, $1-5 \mathrm{~cm}$ tall, with a thick woody procumbent rhizome bearing many prostrate branches with few adventitious roots. Its distribution range encompasses continental Central Asiatic mountains from Kazakhstan to Mongolia. It prefers wet gravel screes, mesic slopes and rock crevices. In Ladakh, this species occurs from 3600 to 6150 m.a.s.l., with optimum between 4500 and 5000 m.a.s.l.

S. gnaphalodes (Royle) Sch. Bip. (Asteraceae) is a perennial herb, $2-6 \mathrm{~cm}$ tall, forming low-density stands of rosettes, borne on long unrooted belowground stems which grow from a main root. Its distribution range encompasses continental Central Asiatic mountains from E. Kazakhstan to Tibet. It grows in screes and on unstable solifluction soils. This species grows in Ladakh at 4650-6150 m.a.s.1.., with optimum between 5200 and 5600 m.a.s.l.

P. attenuata Trin. (Poaceae) is a perennial grass, $3-30 \mathrm{~cm}$ tall, forming dense tussocks with adventitious root system. Its distribution range reaches from southern Siberia and continental Central Asia to humid East Himalayas. It grows on stony steppes, in dry river beds, in screes, on mesic turf and alpine slopes. The species grows in Ladakh from 3250 to 6150 m.a.s.l., with optimum between 5000 and 5500 m.a.s.l.

All six species are known to produce large amounts of wind-borne seeds.

\section{Climate Measurement}

We used TMS loggers (TOMST) to record soil $(10-\mathrm{cm}$ depth), surface and air (10 $\mathrm{cm}$ above) temperature, and average soil moisture down to $10-\mathrm{cm}$ depth (utilising Time Domain Transmission principle). Volumetric water content was calculated from raw Time Domain Transmission measurements according to a formula developed for coarse-grained soils [27]. The loggers were recording hourly values from August 2011 to September 2012. Furthermore, we measured air temperature $(T)$ and relative humidity $(\mathrm{RH})$ using a HOBO U23 Pro v2 logger (Oneset) at 5900 m.a.s.l. from August 2008 to June 2013 (3 cm aboveground, shaded). RH values with a daily mean above $80 \%$ were used as a proxy for snowfall [17]. 


\section{Chemical Characterisation of the Soil and Plant Samples}

Major cations $\left(\mathrm{Ca}^{+2}, \mathrm{Mg}^{+2}, \mathrm{~K}^{+}\right.$and $\left.\mathrm{Na}^{+}\right)$as well as nitrogen and phosphorous species were measured in all soil samples (rhizospheric and bare). Cations were quantified through atomic absorption spectroscopy using SpectrAA 640 (Varian Techtron) at the Analytical Laboratory of the Institute of Botany, Czech Republic. Ammonia, nitrate and total nitrogen were determined colorimetrically after Kjeldahl mineralization using automatic FIAstar 5010 Analyzer (Tecator). Phosphorous was determined colorimetrically after digestion in $\mathrm{HClO}_{4}$ using SHIMADZU UV-1650PC spectrophotometer. To assess the plants' physiological condition, leaf $\delta^{13} \mathrm{C}$ value, and fructan and free sugar (simple sugars) contents were measured. $\delta^{13} \mathrm{C}$ values in the plant leaves, as well as total carbon and nitrogen in the plant leaves and soil, were measured using an elemental analyser coupled to an IRMS at the Stable Isotope Facility, UC Davis, USA (stableisotopefacility. ucdavis.edu). $\delta^{13} \mathrm{C}$ values were used as an integrated, longterm measure of the ratio between internal and ambient $\mathrm{CO}_{2}$ concentrations $(\mathrm{Ci} / \mathrm{Ca})$, which reflects the intrinsic water use efficiency of the plants [28]. Fructan content was determined colorimetrically, and free sugars were quantified using a highperformance anion exchange chromatography with a pulsed amperometric detection [29]. For that we used a Dionex ICS3000 system with electrochemical detector and a Dionex CarboPac PA1 column.

\section{Anatomical Age Determination}

Plant ages were determined by ring counting in the oldest sections in the transition between the hypocotyl and the primary root (root collar). In this zone, all annual rings of perennial plants exist and the reaction to mechanical stress caused by growth seems to be reduced to a minimum [30]. Prior to sectioning, samples were stored in $40 \%$ ethanol. Then, transverse, tangential and radial sections were cut from all studied individuals using a sliding microtome, stained with Astra Blue and Safranin and embedded in Canada Balsam. Microscopic images of these sections were made for counting of the consecutive number of rings and anatomical descriptions [31,32].

\section{Arbuscular Mycorrhizal Fungi Identification}

The presence of arbuscular mycorrhizal fungi (AMF) and dark septate fungi (dark septate endophyte, DSE) in the roots of the studied plants was determined using grid-line intersection light microscopy [33].

\section{DNA Extraction and Illumina MiSeq Sequencing}

DNA was extracted from the roots of each of three replicate plants and from six replicate bare soil samples. For the root samples, the entire dry root system, clean from soil particles (weighing $<0.1 \mathrm{~g}$ in total), was packed into a Lysing Martix E tube (MP Biomedicals), whilst for the soil samples $0.4 \mathrm{~g}$ (dry weight) was used. Extractions were then performed according to a previously published protocol $[34,35]$ and the pellets were resuspended in either 50 (root samples) or $200 \mathrm{ml}$ (soil samples) of low TE buffer $(10 \mathrm{~mm}$ Tris- $\mathrm{HCl}$ and $0.1 \mathrm{~mm}$ EDTA). DNA extracts were checked for quality by electrophoresis and were quantified using Qubit dsDNA HS Assay Kit (Life Technologies). The extracts were used directly as DNA templates for PCR reactions. The root-associated bacterial communities were identified through sequencing of rRNA gene fragments using barcoded high-throughput sequencing [36]. Altogether, we sequenced 24 PCR products (18 from the plant roots +6 bare soil samples). We used primers 343 Fmod (5'-TACGGGWGGCWGCA-3') and 784Rmod (5'GGGTMTCTAATCCBKTT-3') targeting 446 bp in the V3 and V4 regions of the 16S rRNA gene [37]. A set of 24 forward primers each containing a unique 8-bp barcode and one reverse primer were synthesised to serve as sample identifiers (Table S1). PCR amplifications were done in triplicate using the following mixture: each PCR reaction was $25 \mu \mathrm{l}$ in volume and contained $2.5 \mu \mathrm{l} 10 \times$ AccuPrime $^{\mathrm{TM}} \mathrm{PCR}$ buffer I, $1.5 \mathrm{mM} \mathrm{MgCl} 2,0.5 \mu \mathrm{l}$ of Taq DNA polymerase (Invitrogen), $0.25 \mu \mathrm{M}$ of each primer (Sigma-Aldrich) and $1 \mu \mathrm{l}$ of DNA template. The following programme was used for amplification: $94{ }^{\circ} \mathrm{C}$ for $5 \mathrm{~min}$ followed by 28 cycles of $94^{\circ} \mathrm{C}$ for $30 \mathrm{~s}$, $52{ }^{\circ} \mathrm{C}$ for $30 \mathrm{~s}$, and $68{ }^{\circ} \mathrm{C}$ for $30 \mathrm{~s}$ and a single step of final elongation at $68^{\circ} \mathrm{C}$ for $10 \mathrm{~min}$. Following amplification, the samples were pooled and purified using QIAquick PCR Purification Kit (Qiagen). Library preparation and sequencing services were provided by GATC Biotech (Germany). Pairedend sequencing was performed on a MiSeq platform (Illumina) using the v2 Reagent Kits (Illumina). The raw fastq files were deposited into NCBI's SRA database (http://www. ncbi.nlm.nih.gov/sra) and can be found under BioProject accession number PRJNA285086.

\section{Sequence Data Processing and Statistical Analysis}

Processing of raw sequence data was done using mothur v.1.32.1 [38]. In general, we followed the standard operating procedure for MiSeq datasets described by Kozich and colleagues [36] for assembling contigs from the two fastaq files, removing low-quality sequences, trimming the sequences to remove primer and barcode parts, removing singleton reads, and for filtering and removing non-overlapping alignment regions. Sequence alignment and classification were done using SINA V1.29 [39] against the SILVA 115 SSU NR99 database [40]. De novo chimera detection was done using UCHIME [41] and pre-clustering of sequences with up to three bases difference was done using a pseudo-single linkage algorithm according to Huse and colleagues [42]. Operational 
taxonomic units (OTUs) were assigned based on an uncorrected pairwise matrix which was clustered based on a $97 \%$ sequence similarity level using an average neighbour linkage algorithm [43]. Community richness was estimated using the non-parametric Ace estimator and the best-fitted parametric estimator using CatchAll [44], whilst diversity was estimated using Shannon-Wiener, inverse Simpson and Berger-Parker indices (all using mothur). Error propagation for the richness estimators was done using the R package 'propagate' [45, 46]. To account for sample size differences, all samples were subsampled (rarefied) to the minimum sample size $(10,122$ sequences) using bootstrap subsampling at 1000 iterations, for all downstream analyses. Sample means (of richness and diversity estimates) were compared using ANOVA (assuming equal variance) and the differences were tested using Tukey's HSD. Soil and root-associated communities were clustered into metacommunities using Dirichlet multinomial mixtures modelling [47]. For that purpose, the R package 'DirichletMultinomial' [48] was used to consecutively fit Dirichlet mixture models with one to seven components and to derive the corresponding relative abundances of each OTU in the postulated metacommunities. The model fit was calculated using the Laplace approximation to the negative log model evidence, plotted against the number of tested models $(K)$, and the minimum was chosen as the most appropriate model for the data.

\section{Results}

\section{Summary of Climate Conditions at $6150 \mathrm{~m}$}

The mean annual $T$ of the soil in the studied period was $-8.7{ }^{\circ} \mathrm{C}$ and absolute minimum air $T$ was $-36{ }^{\circ} \mathrm{C}(10$ January 2012), whilst absolute maximum air $T$ was $28.2^{\circ} \mathrm{C}$, measured on 15 June 2012. On that day, the maximum daily range of $42.4{ }^{\circ} \mathrm{C}$ was also recorded $\left(\min ,-14.1{ }^{\circ} \mathrm{C}\right.$; max, $28.3^{\circ} \mathrm{C}$ ). The vegetation season - defined either as the period with mean daily air, surface or soil temperatures above zerolasted 82,88 and 89 days, respectively, with mean temperature values of $2.71,3.62$ and $2.97{ }^{\circ} \mathrm{C}$ (mean soil moisture $16.2 \%$ during 89 days) between mid-May and mid-September. Although this may seem to be a long vegetation season, the numbers of days with mean soil or surface temperature above $5{ }^{\circ} \mathrm{C}$ were only 12 and 17 (mean of 5.93 and $6.56^{\circ} \mathrm{C}$ ), respectively. We assume that plant growth was limited almost exclusively to this short period. Freezing of the soil is more critical for vascular plants than aboveground frost. Whilst air temperature during the growing season usually dropped below zero at night for more than $10 \mathrm{~h}$ (regularly to $-7^{\circ} \mathrm{C}$ in the morning hours, absolute minimum of $-16.2^{\circ} \mathrm{C}$ at $4: 30$ a.m. on 17 June 2012), soil temperatures never dropped much below zero and remained between +3 and $-1{ }^{\circ} \mathrm{C}$ (Fig. S2). Above
5800 m.a.s.l., practically all precipitation falls as snow and it can occur all year round. The snowfall during the summer is typically very little in each event $(0-3 \mathrm{~cm})$ and melts after a few hours. Based on relative air humidity as a proxy for snowfall, the total number of days with either a snowfall or with a continuous snow cover was 273 in 2009, 228 in 2010, 132 in 2011 and 141 in 2012.

\section{Chemical Characterisation of the Samples}

All rhizospheric soils (i.e. soil shaken off from the root systems) had similar concentrations of major cations and phosphate, which were in turn similar to the bare soil (Table 1). However, some differences in nitrogen species were notable. The bare soil samples had a much higher concentration of ammonium compared to the rhizospheric soils (6.2 vs. $1.1 \mathrm{mg} \mathrm{kg}^{-1}$ ). The rhizospheric soil of P. attenuata had exceptionally high nitrate and total nitrogen values (10.7 and $651 \mathrm{mg} \mathrm{kg}^{-1}$, respectively). In contrast, no notable differences in the carbon or nitrogen content of the plant tissues were observed. Stable carbon isotope ratios were also similar for all plants, with $\delta$ values ranging between -25.2 and -27.4 . Free sugar and fructan concentrations were relatively low, except in $W$. tridactylites and $S$. gnaphalodes (free sugars and fructan, respectively).

\section{Anatomical Properties of the Plants}

Many common anatomical features were recorded in the studied plants. L. klimesii, D. altaica, W. tridactylites and $S$. gnaphalodes are perennials and have secondary growth and growth or annual rings. The plants had very small rings $(0.03-0.05 \mathrm{~mm})$, which is typical of plants growing under limiting environmental conditions. Common to these species are thick-walled, small and short vessels (10-30 $\mu \mathrm{m}$ in diameter and $40-150 \mu \mathrm{m}$ in length), with simple perforation plates and scalariform to reticulate intervessel pits and absent fibres. Vessel walls are hardly lignified, except in D. altaica. A thick bark is also characteristic of all these species. Dating of L. klimesii, D. altaica and $W$. tridactylites was done by counting the number of rings in their taproots. In S. gnaphalodes, age determination was done by stem ring counts. Due to early decay of the xylem and stem reformation in this species, the number of rings represent the age of the oldest remaining tissue. Ring counting dating was not possible in $P$. attenuata since this species does not produce annual rings and also not for $D$. alshehbazii due to the plants' young age. Number of rings ranged from 4.7 to 15.3 on average, with the exception of one individual of L. klimesii representing 22 rings. These counts were used as estimates of the plant ages, although it cannot be excluded that ring counting underestimates plant age because radial growth may not occur in extremely cold summers. Lastly, the grid-line intersection light 
microscopy method indicated that none of the plants were associated with AMF, although the roots of $P$. attenuata were intensively colonised by a dark septate fungi (DSE).

\section{Richness and Diversity Patterns of Soil and Root-Associated Bacteria}

Out of 721,114 raw sequences, 318,290 passed quality control, of which 7550 were unique (Table 2). Following subsampling (to normalise read depth), the sequences were grouped into 2556 OTUs based on $97 \%$ sequence similarity and average neighbour joining. The number of OTUs per sample ranged between $285 \pm 115$ and $889 \pm 2($ mean \pm SEM) in the root-associated samples. Despite our expectations, the bare soil samples, which had on average $605 \pm 13$ OTUs, were not the richest amongst the samples; rather, these were the root communities of $D$. altaica and $P$. attenuata, with $889 \pm 2$ and $683 \pm 43$ observed OTUs, respectively. Since rarefaction analysis showed insufficient sampling depth (Fig. S3), we used parametric and non-parametric richness estimators to estimate sample richness (Fig. 2). For each sample, 150-300 additional OTUs per sample were predicted by the Ace estimator whilst the parametric estimator predicted up to 700 additional OTUs, but both showed similar trends. The bare soil samples were predicted to be poorer than D. altaica and about as rich as P. attenuata and D. alshehbazii. The bare soil samples also did not harbour the most diverse microbiome from all the samples (Fig. 3). Their inverse Simpson index was significantly lower than that of D. altaica and P. attenuata, whilst their Berger-Parker dominance was one of the highest (although the differences between the samples were insignificant), indicating low diversity and a high dominance of the most abundant OTU. Differences in the Shannon-Wiener index between the bare soil and each of the plant samples were insignificant, but the bare soil nevertheless was the third highest amongst the samples. Reflecting the patterns of observed and predicted richness, the two richest root-associated microbiomes of $D$. altaica and $P$. attenuata were also the most diverse. They were in turn followed by D. alshehbazii, L. klimesii, $S$. gnaphalodes and $W$. tridactylites in a decreasing order of diversity.

\section{Taxonomic Classification of the Bacterial Rhizospheric Communities}

The root-associated and soil bacterial communities were relatively simple in terms of phylogenetic diversity on the order level, with the OTUs being classified primarily into five to eight major orders (Fig. 4). About $8 \%$ of the reads in each community could not be confidently assigned to any microbial group at the order level, and about $12 \%$ of the reads from each community were classified as 'rare' orders (orders comprising $<1 \%$ of the total reads). Sphingomonadales was the only 
Table 2 Summary of sequencing statistics and richness metrics (mean \pm SE, $n=3$ )

\begin{tabular}{lcccccccc}
\hline & D. alshehbazii & D. altaica & L. klimesii & P. attenuata & S. gnaphalodes & W. tridactylites & Soil & Total \\
\hline Raw & $34,030 \pm 1054$ & $33,024 \pm 2517$ & $22,238 \pm 746$ & $18,599 \pm 779$ & $21,853 \pm 4414$ & $25,129 \pm 2632$ & $42,748 \pm 2813$ & 721,114 \\
Passed QC & $13,192 \pm 1055$ & $13,339 \pm 1577$ & $9647 \pm 1445$ & $11,541 \pm 1185$ & $10,214 \pm 4570$ & $11,855 \pm 3442$ & $18,155 \pm 1077$ & 318,290 \\
Unique & $913 \pm 21$ & $1498 \pm 56$ & $626 \pm 10$ & $999 \pm 38$ & $461 \pm 115$ & $496 \pm 101$ & $1086 \pm 47$ & 7550 \\
OTUs & $598 \pm 15$ & $985 \pm 32$ & $407 \pm 17$ & $712 \pm 34$ & $384 \pm 42$ & $311 \pm 67$ & $711 \pm 21$ & 2671 \\
Subsampled OTUs & $550 \pm 2$ & $889 \pm 2$ & $403 \pm 20$ & $683 \pm 43$ & $285 \pm 72$ & $294 \pm 94$ & $605 \pm 13$ & 2556 \\
\hline
\end{tabular}

order that was found in high abundance in both the rootassociated and soil communities, whilst Acidimicrobiales, Burkholderiales and Sphingobacteriales were also common in the soil and on most roots, but to a lesser extent. The rootassociated communities also contained OTUs classified as Rhizobiales in high abundances, but these were relatively rare in the soil samples. Some differences in phylogenetic diversity were also apparent between the root-associated communities. For example, the following orders were abundant in some plants but not others: the order Micrococcales comprised about $5.6 \%$ of the community in D. alshehbazii, Myxococcales comprised about $7.1 \%$ of the community in D. alshehbazii and about $5.5 \%$ in P. attenuata, Acidobacteria subgroup 4 comprised about $6 \%$ of the community in D. altaica and was also abundant in some soil samples, Cytophagales comprised about $4 \%$ of the community in $D$. altaica and $4 \%$ of the communities in $P$. attenuata, Solirubrobacterales comprised about $4 \%$ of the community in D. altaica and was also common in some soil samples,
Pseudomonadales comprised as much as $9.4 \%$ of the community in one of the L. klimesii samples (but was nearly absent in the others) and about $4.4 \%$ of the communities in $W$. tridactylites (in addition to being very prominent in one of the soil samples), and Xanthomonadales comprised about $4.3 \%$ of the communities in D. alshehbazii and about $4 \%$ of the communities in $P$. attenuata.

\section{Identification of Bacterial Metacommunities}

Using Dirichlet multinomial mixtures modelling, the bare soil and root-associated communities were clustered into three metacommunities, from which the samples have supposedly originated (Fig. S4). The three metacommunities had a total mean absolute difference to the reference metacommunity (single component) of $210 \%$, split 58, 67, and $84 \%$ across components, indicating substantial differences in community structures for each component from the reference. The first metacommunity included all the root-associated communities
Fig. 2 Observed richness $(S)$, a non-parametric richness estimation (Ace) and a parametric richness estimation (using CathAll). Means and standard errors in the different plant species and the soil sample. Errors were propagated from the standard errors associated with each replicate. Values were calculated for each sample using bootstrapped subsampling at 1000 iterations. Samples sharing one of the letters appearing next to the symbols are not significantly different $(p<0.05)$

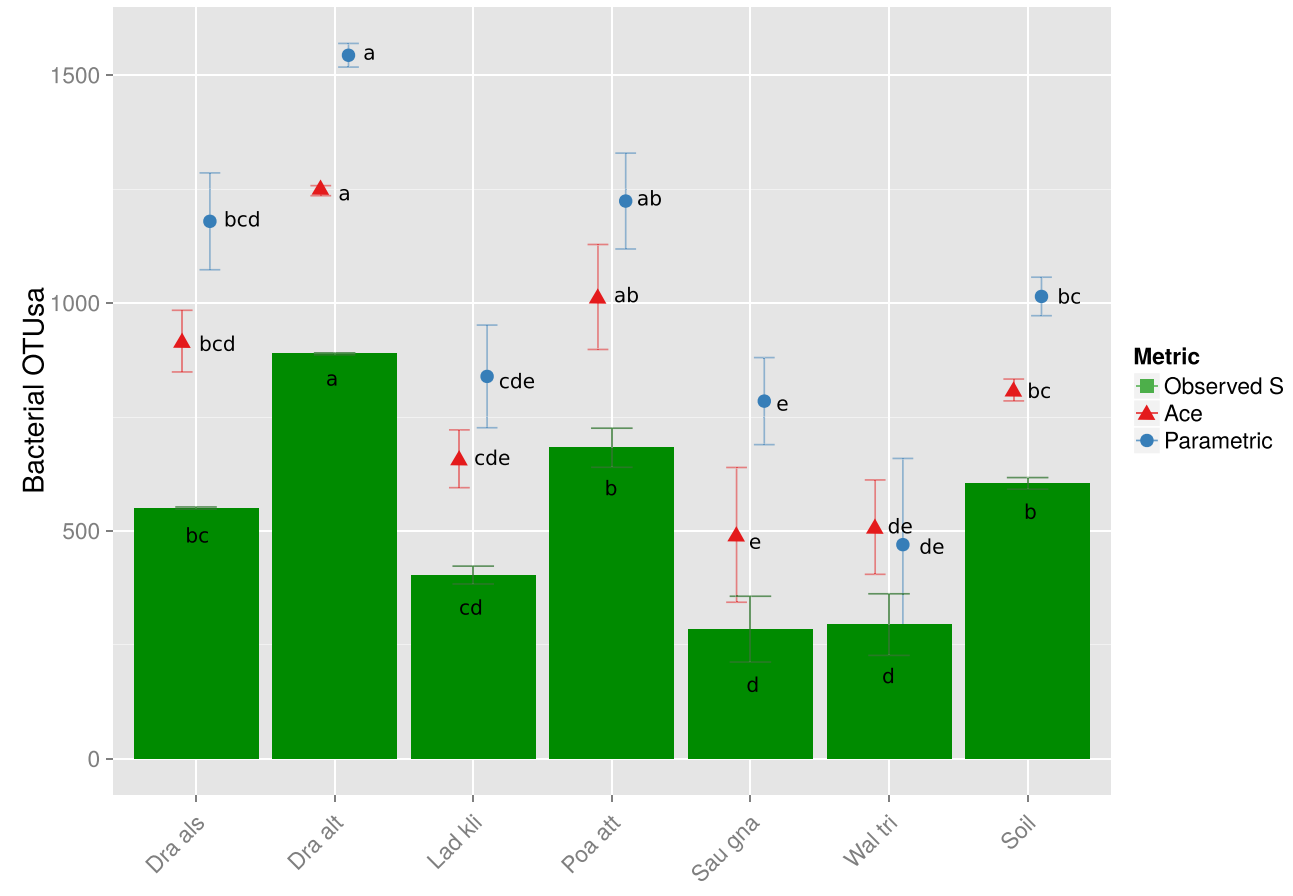


Fig. 3 Shannon-Wiener, inverse Simpson and Berger-Parker diversity indices. Means and standard errors in the different plant species and the soil sample. Errors were propagated from the errors associated with each replicate. Values were calculated for each sample using bootstrapped subsampling of the sequences at 1000 iterations. Samples sharing one of the letters appearing next to the symbols are not significantly different $(p<0.05)$

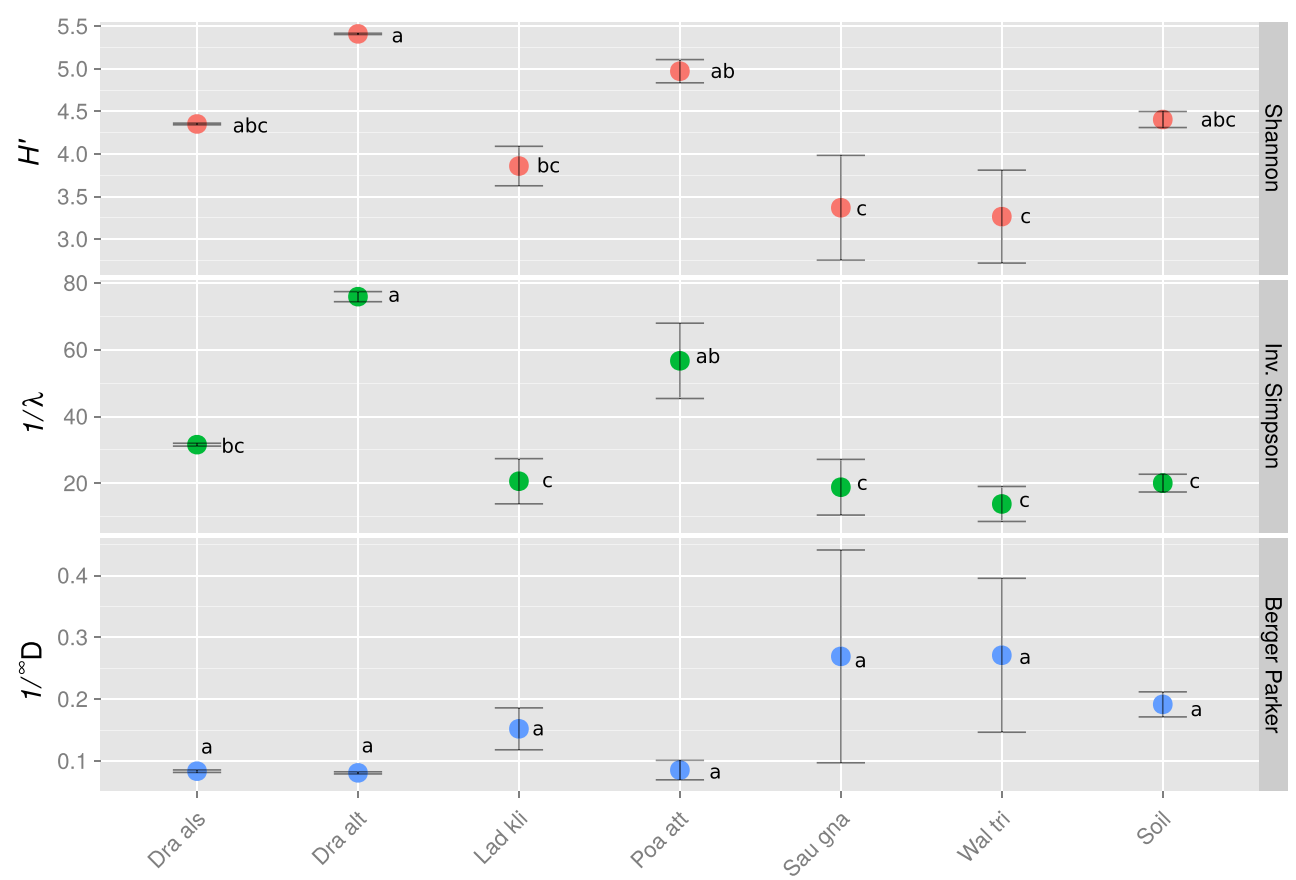

of $D$. altaica, $P$. attenuata and $S$. gnaphalodes, in addition to one of the L. klimesii communities and one of the $W$. tridactylites communities (Fig. 5). This metacommunity had the largest contribution to the mean metacommunity $(\bar{\pi}=0.458)$ and was highly variable $(\bar{\theta}=506)$. The second metacommunity included the remaining two root-associated communities of $L$. klimesii and $W$. tridactylites, in addition to all the rhizosphere communities of D. alshehbazii, and had a weight of 0.292 and a variability of 364. The third metacommunity included only the soil samples. It contributed least to the mean metacommunity $(\bar{\pi}=0.25)$, but was the most variable $(\bar{\theta}=635)$. All three metacommunities are predicted to be dominated by a single OTU assigned as a Sphingomonadales member, with estimated means of 4.65 and $6.63 \%$ in the two rhizophere metacommunities and with $17 \%$ in the soil metacommunity (Table S2), but differentiate in the identity or importance of other dominating OTUs. Primarily, the soil communities, nearly or entirely, lacked two major OTUs assigned as Sphingobacteriales, which were of high abundance in all root-associated communities and accounted for an estimated 12.1 and $0.73 \%$ and 0.4 and $9 \%$ for the first and third OTUs in metacommunities 1 and
Fig. 4 Taxonomic classification and relative abundances of sequences recovered from the root and soil samples.

Representative sequences of each OTU classified at the bacterial order level. Colours of the heat map indicate the cumulative relative abundance of all sequences in a sample classified to a particular order. Grouping (bold lines) separates each sample, whilst numbers on the $X$ axis indicate replicates.

Unclassified: sequences with $<70 \%$ classification agreement. Rare: all taxa comprising each $<1 \%$ of the sequences

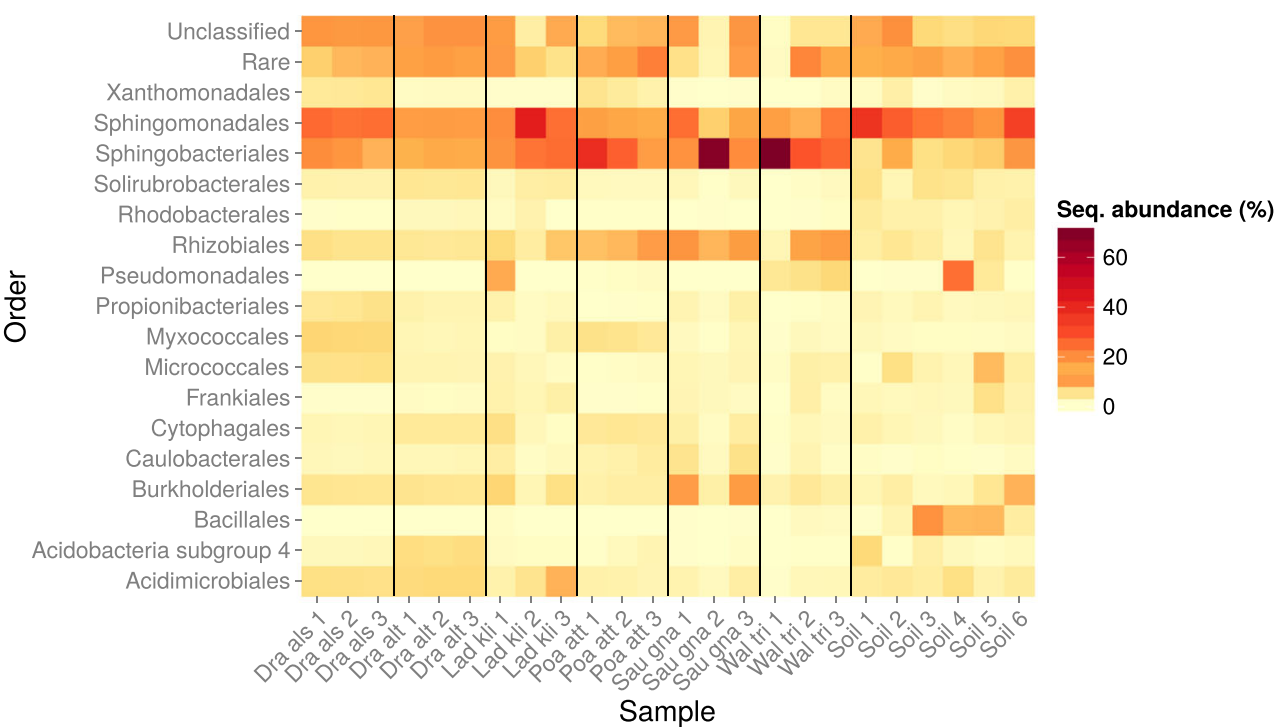


Fig. 5 Sample clustering to metacommunities together with a heat map of the root-associated and soil bacterial OTU dataset with hierarchical clustering. Heat map shows the root-associated and soil bacterial OTU abundances (square-root-transformed), with samples grouped according to the metacommunity from which they most likely have originated. The mean of the Dirichlet component for that mixture is shown to the right of each metacommunity. Only the first 30 OTUs are shown, those with the greatest variability across metacommunities (see Table S2 for details)

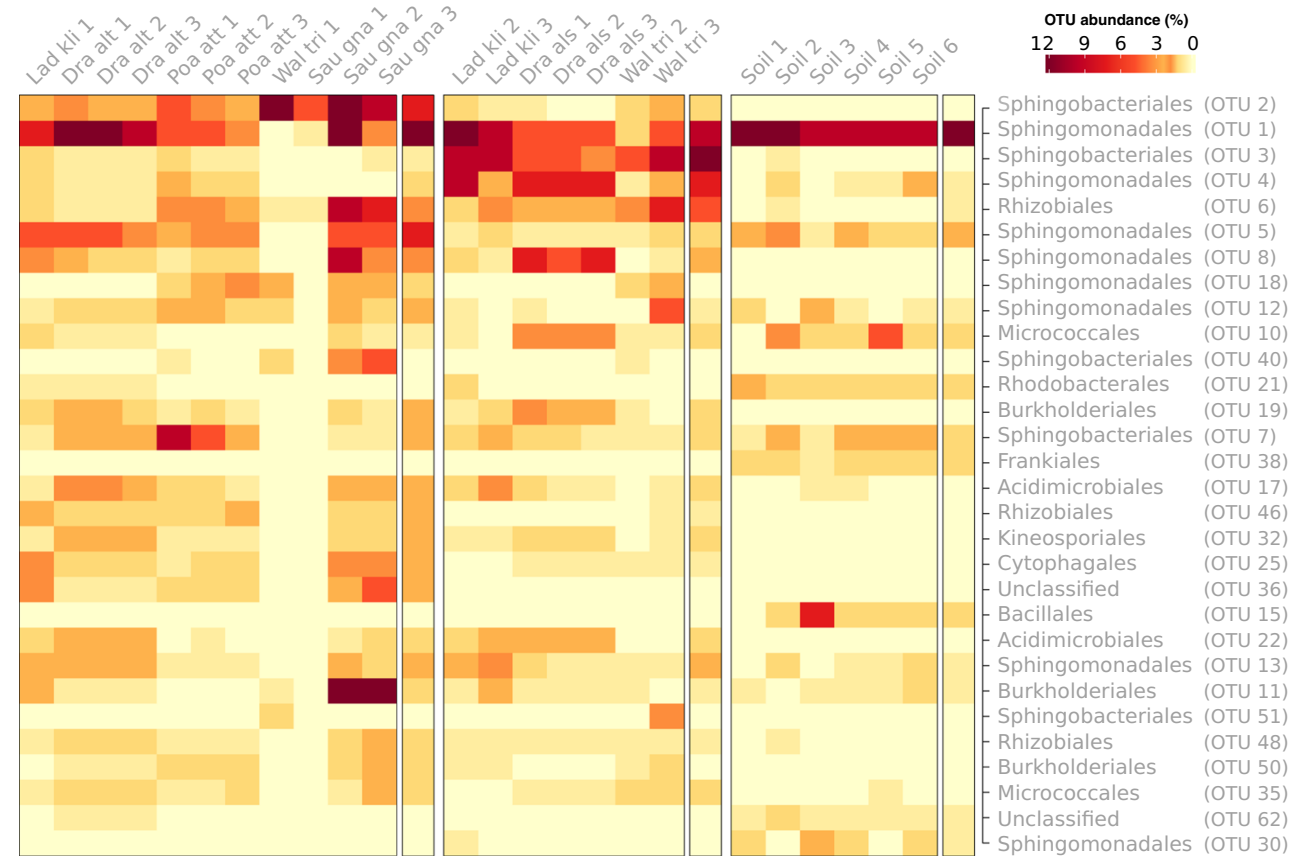

2 , respectively. Additional notable differences were the presence of dominant Rhizobiales and Burkholderiales OTUs, as well as several OTUs assigned to Sphingomonadales, on the roots but not in the soil. In contrast, Frankiales and Bacillales were found almost exclusively in the bare soil communities.

\section{Discussion}

Here, we report on the occurrence of six vascular plants at an unprecedented altitude of 6150 m.a.s.l. and characterise their habitat and their root-associated and bare soil bacterial community. The six plant species were all growing under highly stressful conditions, but nevertheless indicated stable growth. Out of the four plant species for which age could be determined, three were very young ( $<10$ years), whilst one (L. klimesii) was 15 years on average, providing evidence to the recent upward migration of the plants and the rapid changes these Western Himalayan slopes undergo. Nevertheless, the monitored temperature and snow cover profiles indicated that the plants could probably utilise no more than a few weeks per year for growth. The high $\delta^{13} \mathrm{C}$ values, which are typical of plants growing at high altitude [16], indicate high water use efficiency imposed by stress conditions caused by drought and frost. In addition, the high concentrations of fructan in L. klimesii and $W$. tridactylites and soluble sugars in $W$. tridactylites and D. altaica could also indicate growth retardation (but could also serve as compatible solutes, combating water deficit caused by drought or frost) [49, 50]. Only minor changes in the chemical composition of the rhizosphere soil could be observed compared to the bare soil. Most notably, a decrease in ammonia concentrations was observed, which is either due to the presence of biological soil crusts or the high uptake by plants.

Despite their young age and the poorly developed soil, the plants harboured several hundred observable OTUs on their roots (with more than 1000 predicted), with community richness not correlating to plant age (data not shown). Surprisingly, other studies performing amplicon sequencing of rhizosphere and rhizoplane bacteria on divergent plants ranging from wild plants growing on the shores of an Antarctic bay [51] to cultivated rice [52] and maize [53] growing on fully developed soils have reported similar richness values (approx. 300-1000 OTUs), demonstrating the remarkable ability of microbes to saturate the niches around the roots even in such harsh and poor environment.

As expected from a young and poorly developed soil, it was poorer in OTUs compared to most other studied mature soils, which typically harbour 800-2000 observed OTUs and up to 5000 estimated total OTUs (e.g. [54, 55]), although it was similar to or even richer than other mature desert soils [56-58]. To our surprise, the soil communities showed similar richness to the rhizoplane communities and were even poorer than the communities on the roots of P. attenuata and D. altaica. This contrasts our initial hypothesis that the soil acts as a microbial reservoir from which the plant roots recruit their associates.

All root-associated communities were dominated by a similar and relatively small number of bacterial orders. Superficially, the community composition of the root- 
associated samples was similar between plants and resembled that of the bare soil. All communities were dominated primarily by members of the order Sphingomonadales (Alphaproteobacteria), whilst the root samples also had high proportions of Sphingobacteriales (Bacteroidetes), Rhizobiales (Alphaproteobacteria) and Burkholderiales (Betaproteobacteria). On the class level (i.e. alpha- and betaproteobacteria, and Bacteroidetes), these bacteria are typical of root environments; however, many of the orders are uncommon. Together with the high proportions of Actinobacteria (e.g. Solirubrobacterales and Propionibacteriales) and the low proportions of Acidobacteriales (Acidobacteria), the bare soil and rootassociated communities were highly typical of soils and crusts from hot or arctic deserts [59-61], but very different from the soil or root-associated communities found at high-altitude temperate regions [62-64]. The latter were more diverse on the class level and were characterised by high proportions of Acidobacteria, gamma- and deltaproteobacteria and Planctomycetes and consecutively lower proportions of alpha- and betaproteobacteria and Actinobacteria. In particular, Sphingomonadales and Sphingobacteriales were also found to dominate and be very active in biological soil crusts from the Negev Desert [56] and in soils recovered from the Atacama [65] and Death Valley deserts [66], but to our knowledge have never been reported as the dominant members of root-associated communities. This demonstrates that whilst subnival zones and glacial forefields select for specifically adapted bacteria [67], the resulting bacterial community nevertheless resembles that of the surrounding ecosystem (i.e. arid), which acts as the major source of inoculation [68].

Root-associated bacterial communities play diverse roles in helping plants establish. Since all were devoid of associated mycorrhiza, the plants must have relied on prokaryotes for support in acquiring minerals. Biologically fixed nitrogen is one of the most limiting factors in newly deglaciated soils and, consequently, also one of the first microbial processes to establish in such sites [69]. Pioneer plants have also been shown to harbour active diazotrophs on their roots, displaying an overall higher population density and activity than the surrounding soil $[64,70]$. As mentioned above, the presence of members of Rhizobiales on the plant roots but not in the soil is a strong indication of root-associated diazotrophy. In addition, whilst to our knowledge never directly demonstrated, members of the order Sphingomonadales possess the nitrogenase gene and could possibly act as root-associated diazotrophs (in contrast to symbiotic diazotrophs) [71]. Sphingomonadales are also known to utilise a wide range of naturally occurring compounds including root exudates and are commonly found on plant roots [72, 73]. Sphingobacteriales have also been found on the roots of some plants in the past and have been shown to utilise root exudates [72]. Members of this order are heterotrophs known to utilise a wide variety of carbon sources
[74] and are also often detected in hydrocarbon-contaminated soils [75].

The extent to which the root-associated bacterial community is contingent with specific plant species is still debated. Various studies, particularly on cultivated plants, have found large variations in community structure based on the plant species studied (e.g. [72, 76, 77]). Yet in many field studies where wild plants growing in vicinity were studied, no significant differences in bacterial communities between plant species were detected, or they were very small. For example, Nunan and colleagues [78] studying grasslands in the UK and Teixeira and colleagues [51] studying vascular plants in the Antarctic were unable to cluster root-associated bacteria by plant species, indicating that, for wild plants growing under natural conditions, the environment plays a much stronger role in determining the associated community than the plant species. In this study, the main bacterial orders were shared between nearly all plants, yet the root-associated communities were clustered into two distinct metacommunities. An examination of these metacommunities shows that they mostly split based on the relative abundance of some dominant Sphingobacteriales and Sphingomonadales OTUs and not on presence or absence. Since the possible physiological differences between these OTUs are unknown, it remains unclear whether these differences can be attributed to more than stochastic colonisation processes.

Clear differences were however found between the rootassociated communities and the surrounding soil, separating them into distinct metacommunities. Whilst both the plant and bare soil metacommunities were dominated by members of the same bacterial orders, many of the dominant OTUs in the plants (most notably OTUs 2, 3, 8, 18 and 40) were missing in the soil. Some of these bacteria, such as Rhizobiales, are well known for forming root associations and are expected to be absent or nearly absent in soil, whilst others such as Sphingobacteriales and Sphingomonadales were dominant in both soil and root communities, but were represented by different OTUs, which could differ significantly in their ecophysiology. Likewise, some highly ranked OTUs in the soil communities were absent in the root-associated ones (most notably OTU 15 classified as Bacillales and OTU 38 classified as Frankiales). This stands in contrast to previous reports on the rhizospheric microbial community of pioneer plants in glacial forefields (e.g. [79-81]) which found no difference between soil and root-associated communities. However, this discrepancy could probably be explained by the use of a more sensitive and robust community profiling technique in this work (high-throughput sequencing compared to molecular fingerprinting techniques). Whilst the complete absence of these dominant root-associated OTUs in the soil cannot be fully proven, the differences between root and bare soil communities, together with the fact that the soil was not richer than several of the plants, imply that some bacteria were 
transported on, or in, the dispersing plant seeds and later became part of the root-associated microbial community. The fact that plant seeds harbour a diverse and viable microbial community on and in them is evident from numerous studies [82]. Moreover, studies have shown that seed-borne bacterial communities tend to resemble those of the soil from which the mother plant was grown [83] and that some of these bacteria (including also certain rhizobia) make their way later on to the root surface and rhizosphere of the germinating plants [83-85]. The transport and later proliferation of certain bacteria on the roots, following germination, could explain the source of the OTUs not present in the surrounding soil. This indicates that pioneer plants do not only recruit microbes from the surrounding soil but also enrich the soil with allochthonous bacteria and help establish a mature bacterial soil community.

Acknowledgments Open access funding provided by Max Planck Society (Max Planck Institute for Terrestrial Microbiology).

Open Access This article is distributed under the terms of the Creative Commons Attribution 4.0 International License (http:// creativecommons.org/licenses/by/4.0/), which permits unrestricted use, distribution, and reproduction in any medium, provided you give appropriate credit to the original author(s) and the source, provide a link to the Creative Commons license, and indicate if changes were made.

\section{References}

1. Chen I-C, Hill JK, Ohlemüller R et al (2011) Rapid range shifts of species associated with high levels of climate warming. Science 333:1024-1026. doi:10.1126/science. 1206432

2. Chapin FS, Walker LR, Fastie CL, Sharman LC (1994) Mechanisms of primary succession following deglaciation at Glacier Bay, Alaska. Ecol Monogr 64:149-175. doi:10.2307/ 2937039

3. Holzinger B, Hülber K, Camenisch M, Grabherr G (2007) Changes in plant species richness over the last century in the eastern Swiss Alps: elevational gradient, bedrock effects and migration rates. Plant Ecol 195:179-196. doi:10.1007/s11258-007-9314-9

4. Dolezal J, Homma K, Takahashi K et al (2008) Primary succession following deglaciation at Koryto Glacier Valley, Kamchatka. Arct Antarct Alp Res 40:309-322. doi:10.1657/1523-0430(06-123) [DOLEZAL]2.0.CO;2

5. Matthews JA (1992) The ecology of recently-deglaciated terrain: a geoecological approach to glacier forelands. Cambridge University Press, Cambridge

6. Schütte UME, Abdo Z, Bent SJ et al (2009) Bacterial succession in a glacier foreland of the High Arctic. ISME J 3:1258-1268. doi:10. 1038/ismej.2009.71

7. Zumsteg A, Luster J, Göransson H et al (2012) Bacterial, archaeal and fungal succession in the forefield of a receding glacier. Microb Ecol 63:552-564. doi:10.1007/s00248-011-9991-8

8. Nemergut DR, Anderson SP, Cleveland CC et al (2007) Microbial community succession in an unvegetated, recently deglaciated soil. Microb Ecol 53:110-122. doi:10.1007/ s00248-006-9144-7
9. Nicol GW, Tscherko D, Embley TM, Prosser JI (2005) Primary succession of soil Crenarchaeota across a receding glacier foreland. Environ Microbiol 7:337-347. doi:10.1111/j.1462-2920.2005. 00698.x

10. Aschenbach K, Conrad R, Řeháková K et al (2013) Methanogens at the top of the world: occurrence and potential activity of methanogens in newly deglaciated soils in high-altitude cold deserts in the Western Himalayas. Front Microbiol 4:359. doi:10.3389/ fmicb.2013.00359

11. Türk R, Gärtner G (2003) Biological soil crusts of the subalpine, alpine, and nival areas in the Alps. In: Belnap J, Lange OL (eds) Biological soil crusts: structure, function and management. Springer-Verlag, Berlin, pp 3-30

12. Sattin SR, Cleveland CC, Hood E et al (2010) Functional shifts in unvegetated, perhumid, recently-deglaciated soils do not correlate with shifts in soil bacterial community composition. J Microbiol 47: 673-681. doi:10.1007/s12275-009-0194-7

13. Schmidt SK, Reed SC, Nemergut DR et al (2008) The earliest stages of ecosystem succession in high-elevation (5000 metres above sea level), recently deglaciated soils. Proc R Soc B 275: 2793-2802. doi:10.1098/rspb.2008.0808

14. de Richter DB, Oh N-H, Fimmen R, Jackson J (2007) The rhizosphere and soil formation. In: Cardon ZG, Whitbeck JL (eds) The rhizosphere: an ecological perspective. Elsevier Academic, Burlington, pp 179-200

15. Klimeš L, Doležal J (2010) An experimental assessment of the upper elevational limit of flowering plants in the Western Himalayas. Ecography 33:590-596. doi:10.1111/j.1600-0587. 2009.05967.x

16. Körner C (2011) Coldest places on earth with angiosperm plant life. Alp Bot 121:11-22. doi:10.1007/s00035-011-0089-1

17. Dvorský M, Altman J, Kopecký M et al (2015) Vascular plants at extreme elevations in eastern Ladakh, northwest Himalayas. Plant Ecol Divers 8:571-584. doi:10.1080/17550874.2015.1018980

18. Manoharachary C, Mukerji KG (2006) Rhizosphere biologyan overview. In: Mukerji KG, Manoharachary C, Singh J (eds) Microbial activity in the rhizosphere. Springer, Heidelberg, pp $1-16$

19. Singh G, Mukerji KG (2006) Root exudates as determinant of rhizospheric microbial biodiversity. In: Mukerji KG, Manoharachary C, Singh J (eds) Microbial activity in the rhizosphere. Springer, Heidelberg, pp 39-54

20. Philippot L, Raaijmakers JM, Lemanceau P, van der Putten WH (2013) Going back to the roots: the microbial ecology of the rhizosphere. Nat Rev Microbiol 11:789-799. doi:10.1038/nrmicro3109

21. Hawkes CV, DeAngelis KM, Firestone MK (2007) Root interactions with soil microbial communities and processes. In: Cardon ZG, Whitbeck JL (eds) The rhizosphere: an ecological perspective. Elsevier Academic, Burlington, pp 179-200

22. Dvorský M, Doležal J, de Bello F, Klimešová JK (2011) Vegetation types of East Ladakh: species and growth form composition along main environmental gradients. Appl Veg Sci 14:132-147. doi:10. 1111/j.1654-109X.2010.01103.x

23. Bolch T, Kulkarni A, Kääb A et al (2012) The state and fate of Himalayan glaciers. Science 336:310-314. doi:10.1126/science. 1215828

24. Bhutiyani MR, Kale VS, Pawar NJ (2007) Long-term trends in maximum, minimum and mean annual air temperatures across the northwestern Himalaya during the twentieth century. Clim Chang 85:159-177. doi:10.1007/s10584-006-9196-1

25. Shrestha UB, Gautam S, Bawa KS (2012) Widespread climate change in the Himalayas and associated changes in local ecosystems. PLoS ONE 7:e36741. doi:10.1371/journal.pone.0036741

26. Klimešová J, Doležal J, Dvorský M et al (2011) Clonal growth forms in eastern Ladakh, Western Himalayas: classification and 
habitat preferences. Folia Geobot 46:191-217. doi:10.1007/ s12224-010-9076-3

27. Vlček V (2010) Calibration of the water content sensor TMS for mineral and organic soils. BSc thesis, České vysoké učení technické

28. Farquhar G, O'Leary M, Berry J (1982) On the relationship between carbon isotope discrimination and the intercellular carbon dioxide concentration in leaves. Funct Plant Biol 9:121-137

29. Chlumská Z, Janeček Š, Doležal J (2013) How to preserve plant samples for carbohydrate analysis? Test of suitable methods applicable in remote areas. Folia Geobot 49:1-15. doi:10.1007/s12224013-9153-5

30. Schweingruber F, Poschlod P (2005) Growth rings in herbs and shrubs: life span, age determination and stem anatomy. For Snow Landsc Res 79:195-415

31. Wheeler EA, Baas P, Gasson PE (1989) IAWA list of microscopic features for hardwood ident ification: with an appendix on nonanatomical information. IAWA Bull 10:219-332

32. Schweingruber FH, Börner A, Schulze E-D (2011) Atlas of stem anatomy in herbs, shrubs and trees: volume 1. Springer Science \& Business Media, Dordrecht

33. Giovannetti M, Mosse B (1980) An evaluation of techniques for measuring vesicular arbuscular mycorrhizal infection in roots. New Phytol 84:489-500. doi:10.1111/j.1469-8137.1980.tb04556.x

34. Angel R, Claus P, Conrad R (2012) Methanogenic archaea are globally ubiquitous in aerated soils and become active under wet anoxic conditions. ISME J 6:847-862. doi:10.1038/ismej.2011.141

35. Angel R (2012) Total nucleic acid extraction from soil. Protoc Exch. doi:10.1038/protex.2011.204

36. Kozich JJ, Westcott SL, Baxter NT et al (2013) Development of a dual-index sequencing strategy and curation pipeline for analyzing amplicon sequence data on the miseq Illumina sequencing platform. Appl Environ Microbiol 79:5112-5120. doi:10.1128/AEM.0104313

37. Köhler T, Dietrich C, Scheffrahn RH, Brune A (2012) Highresolution analysis of gut environment and bacterial microbiota reveals functional compartmentation of the gut in wood-feeding higher termites (Nasutitermes spp.). Appl Environ Microbiol 78: 4691-4701. doi:10.1128/AEM.00683-12

38. Schloss PD, Westcott SL, Ryabin T et al (2009) Introducing mothur: open source, platform-independent, community-supported software for describing and comparing microbial communities. Appl Environ Microbiol 75:75377541. doi:10.1128/AEM.01541-09

39. Pruesse E, Peplies J, Glöckner FO (2012) SINA: accurate high throughput multiple sequence alignment of ribosomal RNA genes. Bioinformatics 28:1823-1829. doi:10.1093/bioinformatics

40. Pruesse E, Quast C, Knittel K et al (2007) SILVA: a comprehensive online resource for quality checked and aligned ribosomal RNA sequence data compatible with ARB. Nucleic Acids Res 35: 7188-7196. doi:10.1093/nar

41. Edgar RC, Haas BJ, Clemente JC et al (2011) UCHIME improves sensitivity and speed of chimera detection. Bioinformatics 27: 2194-2200. doi:10.1093/bioinformatics

42. Huse SM, Welch DM, Morrison HG, Sogin ML (2010) Ironing out the wrinkles in the rare biosphere through improved OTU clustering. Environ Microbiol 12:1889-1898. doi:10.1111/j.1462-2920. 2010.02193.x

43. Schloss PD, Westcott SL (2011) Assessing and improving methods used in operational taxonomic unit-based approaches for 16S rRNA gene sequence analysis. Appl Environ Microbiol 77:3219-3226. doi:10.1128/AEM.02810-10

44. Bunge J (2011) Estimating the number of species with catchall. Pac Symp Biocomput 2011:121-130

45. R Core Team (2012) R: a language and environment for statistical computing. R Foundation for Statistical Computing, Vienna

46. Spiess A-N (2014) Propagate: propagation of uncertainty. R package
47. Holmes I, Harris K, Quince C (2012) Dirichlet multinomial mixtures: generative models for microbial metagenomics. PLoS ONE 7:e30126. doi:10.1371/journal.pone.0030126

48. Morgan M (2014) Dirichlet multinomial: Dirichlet-multinomial mixture model machine learning for microbiome data. $\mathrm{R}$ package

49. Körner C (2003) Alpine plant life: functional plant ecology of high mountain ecosystems. Springer Science \& Business Media, Dordrecht

50. Valluru R, den Ende WV (2008) Plant fructans in stress environments: emerging concepts and future prospects. J Exp Bot 59: 2905-2916. doi:10.1093/jxb/ern164

51. Teixeira LCRS, Peixoto RS, Cury JC et al (2010) Bacterial diversity in rhizosphere soil from Antarctic vascular plants of Admiralty Bay, maritime Antarctica. ISME J 4:989-1001. doi:10.1038/ismej.2010. 35

52. Edwards J, Johnson C, Santos-Medellín C et al (2015) Structure, variation, and assembly of the root-associated microbiomes of rice. Proc Natl Acad Sci 112:E911-E920. doi:10.1073/pnas. 1414592112

53. Peiffer JA, Spor A, Koren O et al (2013) Diversity and heritability of the maize rhizosphere microbiome under field conditions. Proc Natl Acad Sci 110:6548-6553. doi:10.1073/pnas.1302837110

54. Nacke H, Thürmer A, Wollherr A et al (2011) Pyrosequencingbased assessment of bacterial community structure along different management types in German forest and grassland soils. PLoS ONE 6:e17000. doi:10.1371/journal.pone.0017000

55. Roesch LFW, Fulthorpe RR, Riva A et al (2007) Pyrosequencing enumerates and contrasts soil microbial diversity. ISME J 1:283290

56. Angel R, Conrad R (2013) Elucidating the microbial resuscitation cascade in biological soil crusts following a simulated rain event. Environ Microbiol 15:2799-2815. doi:10.1111/1462-2920.12140

57. Neilson JW, Quade J, Ortiz M et al (2012) Life at the hyperarid margin: novel bacterial diversity in arid soils of the Atacama Desert, Chile. Extremophiles 16:553-566. doi:10.1007/s00792-012-0454z

58. Steven B, Gallegos-Graves LV, Belnap J, Kuske CR (2013) Dryland soil microbial communities display spatial biogeographic patterns associated with soil depth and soil parent material. FEMS Microbiol Ecol 86:101-113. doi:10.1111/1574-6941.12143

59. Makhalanyane TP, Valverde A, Gunnigle E et al (2015) Microbial ecology of hot desert edaphic systems. FEMS Microbiol Rev 39: 203-221. doi:10.1093/femsre/fuu011

60. Mapelli F, Marasco R, Rizzi A et al (2010) Bacterial communities involved in soil formation and plant establishment triggered by pyrite bioweathering on Arctic moraines. Microb Ecol 61:438447. doi:10.1007/s00248-010-9758-7

61. Fierer N, Strickland MS, Liptzin D et al (2009) Global patterns in belowground communities. Ecol Lett 12:1238-1249. doi:10.1111/j. 1461-0248.2009.01360.x

62. Rime T, Hartmann M, Brunner I et al (2015) Vertical distribution of the soil microbiota along a successional gradient in a glacier forefield. Mol Ecol 24:1091-1108. doi:10.1111/mec.13051

63. Yarwood S, Wick A, Williams M, Daniels WL (2014) Parent material and vegetation influence soil microbial community structure following 30-years of rock weathering and pedogenesis. Microb Ecol 69:383-394. doi:10.1007/s00248-014-0523-1

64. Knelman JE, Legg TM, O'Neill SP et al (2012) Bacterial community structure and function change in association with colonizer plants during early primary succession in a glacier forefield. Soil Biol Biochem 46:172-180. doi:10.1016/j.soilbio.2011.12.001

65. Lester ED, Satomi M, Ponce A (2007) Microflora of extreme arid Atacama Desert soils. Soil Biol Biochem 39:704-708. doi:10.1016/ j.soilbio.2006.09.020

66. Prestel E, Regeard C, Salamitou S et al (2013) The bacteria and bacteriophages from a Mesquite Flats site of the Death Valley 
Desert. Antonie Van Leeuwenhoek 103:1329-1341. doi:10.1007/ s10482-013-9914-4

67. Stres B, Sul WJ, Murovec B, Tiedje JM (2013) Recently delaciated high-altitude soils of the Himalaya: diverse environments, heterogenous bacterial communities and long-range dust inputs from the upper troposphere. PLoS ONE 8:e76440. doi:10.1371/journal. pone.0076440

68. Bakker PAHM, Berendsen RL, Doornbos RF et al (2013) The rhizosphere revisited: root microbiomics. Front Plant Sci 4:165. doi:10.3389/fpls.2013.00165

69. Brankatschk R, Töwe S, Kleineidam K et al (2011) Abundances and potential activities of nitrogen cycling microbial communities along a chronosequence of a glacier forefield. ISME J 5:10251037. doi:10.1038/ismej.2010.184

70. Töwe S, Albert A, Kleineidam K et al (2010) Abundance of microbes involved in nitrogen transformation in the rhizosphere of Leucanthemopsis alpina (1.) Heywood grown in soils from different sites of the Damma Glacier forefield. Microb Ecol 60:762-770. doi: 10.1007/s00248-010-9695-5

71. Kämpfer P, Denner EBM, Meyer S et al (1997) Classification of Pseudomonas azotocolligans Anderson 1955, 132, in the genus Sphingomonas as Sphingomonas trueperi sp. nov. Int J Syst Bacteriol 47:577-583. doi:10.1099/00207713-47-2-577

72. Haichar FZ, Marol C, Berge O et al (2008) Plant host habitat and root exudates shape soil bacterial community structure. ISME J 2: 1221-1230. doi:10.1038/ismej.2008.80

73. Qiu Q, Conrad R, Lu Y (2009) Cross-feeding of methane carbon among bacteria on rice roots revealed by DNA-stable isotope probing. Environ Microbiol Rep 1:355-361. doi:10.1111/j.1758-2229. 2009.00045.x

74. Shivaji S, Ray MK, Rao NS et al (1992) Sphingobacterium antarcticus sp. nov., a psychrotrophic bacterium from the soils of Schirmacher Oasis, Antarctica. Int J Syst Bacteriol 42:102-106. doi:10.1099/00207713-42-1-102

75. Mao J, Luo Y, Teng Y, Li Z (2012) Bioremediation of polycyclic aromatic hydrocarbon-contaminated soil by a bacterial consortium and associated microbial community changes. Int Biodeterior Biodegrad 70:141-147. doi:10.1016/j.ibiod.2012.03.002
76. Bardgett RD, Walker LR (2004) Impact of coloniser plant species on the development of decomposer microbial communities following deglaciation. Soil Biol Biochem 36:555-559. doi:10.1016/j. soilbio.2003.11.002

77. Kowalchuk GA, Buma DS, de Boer W et al (2002) Effects of above-ground plant species composition and diversity on the diversity of soil-borne microorganisms. Antonie Van Leeuwenhoek 81: 509-520. doi:10.1023/A:1020565523615

78. Nunan N, Daniell TJ, Singh BK et al (2005) Links between plant and rhizoplane bacterial communities in grassland soils, characterized using molecular techniques. Appl Environ Microbiol 71:67846792. doi:10.1128/AEM.71.11.6784-6792.2005

79. Tscherko D, Hammesfahr U, Zeltner G et al (2005) Plant succession and rhizosphere microbial communities in a recently deglaciated alpine terrain. Basic Appl Ecol 6:367-383. doi:10.1016/j.baae. 2005.02.004

80. Miniaci C, Bunge M, Duc L et al (2007) Effects of pioneering plants on microbial structures and functions in a glacier forefield. Biol Fertil Soils 44:289-297. doi:10.1007/s00374-007-0203-0

81. Řeháková K, Chroňáková A, Krištůfek V et al (2015) Bacterial community of cushion plant Thylacospermum ceaspitosum on elevational gradient in the Himalayan cold desert. Terr Microbiol 6:304. doi:10.3389/fmicb.2015.00304

82. Nelson EB (2004) Microbial dynamics and interactions in the spermosphere. Annu Rev Phytopathol 42:271-309. doi:10.1146/ annurev.phyto.42.121603.131041

83. Green SJ, Inbar E, Michel FC et al (2006) Succession of bacterial communities during early plant development: transition from seed to root and effect of compost amendment. Appl Environ Microbiol 72:3975-3983. doi:10.1128/AEM.02771-05

84. Pérez-Ramírez NO, Rogel MA, Wang E et al (1998) Seeds of Phaseolus vulgaris bean carry Rhizobium etli. FEMS Microbiol Ecol 26:289-296. doi:10.1111/j.1574-6941.1998.tb00513.x

85. Normander B, Prosser JI (2000) Bacterial origin and community composition in the barley phytosphere as a function of habitat and presowing conditions. Appl Environ Microbiol 66:4372-4377. doi: 10.1128/AEM.66.10.4372-4377.2000 